\title{
Alms-Awareness Behavior, Serotonin Hormone, and Corporate Age
}

\author{
La Ode Sumail and Hasbiyadi \\ Sekolah Tinggi Ilmu Ekonomi Makassar (STIEM) Bongaya, Indonesia \\ Email: \\ odesumail@yahoo.co.id; hasbiyadi@stiem-bongaya.co.id
}

\begin{abstract}
Humans who are fragmented in their souls or (split personality) are easily infested with mental poisons, so we need detolks in the form of alms. We investigate the influence of religiosity, attitudes and subjective norms on alms awareness and impact on corporate age through the role of the hormone serotonin. Because the characteristics of PT Haji La Tunrung's ownership are family ownership and are currently directed by second generation family members, it is interesting to be chosen as the object of research. We believe that owners, managers and employees can provide accurate and quality information (purposive sampling) and analyze data using WarpPLS 7.0. We find that the better religiosity, attitudes and subjective norms the higher the awareness of charity and the age of corporations increases. Sadaqah awareness can increase the hormone serotonin. Therefore, the hormone serotonin can increase self-confidence for individuals and corporations and performance is good so that the age of corporations increases. We also find that higher levels of formal education are not the only determinant of alms awareness.
\end{abstract}

Key words: Alms awareness, serotonin hormone, corporate age.

\begin{abstract}
Abstrak: Manusia yang terpecah-pecah jiwanya (split personality) mudah dihinggapi oleh racun jiwa maka diperlukan detolks berupa sedekah. Kami menginvestigasi pengaruh religiusitas, sikap dan norma subjektif terhadap kesadaran bersedekah dan berdampak pada umur korporasi melalui peran hormon serotonin. Karena karakteristik kepemilikan PT Haji La Tunrung adalah kepemilikan keluarga dan saat ini dinahkodai oleh anggota keluarga generasi kedua, maka menarik untuk dipilih menjadi objek penelitian. Kami meyakini pemilik, manajer dan karyawan dapat memberikan informasi yang akurat dan berkualitas (purposive sampling) dan data dianalisis menggunakan WarpPLS 7.0. Kami menemukan bahwa semakin baik religiusitas, sikap dan norma subjektif semakin tinggi kesadaran bersedekah dan umur korporasi semakin bertambah. Kesadaran bersedekah dapat meningkatkan hormon serotonin. Karena itu, hormon serotonin dapat meningkatkan kepercayaan diri bagi individu dan korporasi dan kinerja menjadi baik sehingga umur korporasi semakin bertambah. Kami menemukan pula bahwa jenjang pendidikan formal yang lebih tinggi bukan satu-satunya penentu kesadaran bersedekah.
\end{abstract}

Kata kunci: Kesadaran bersedekah, hormone serotonin, umur korporasi. 


\section{INTRODUCTION}

At present, Muslims feel stricken by spiritual disasters that tend to distance from Rabbaniyah's values. Human beings often display hedonism and materialism oriented behavior. As a result, human beings are a fragmented soul (split personality). It easily infests by mental poisons such as the fluctuation of life, anxiety, and chaos of the mind. Toxins, detox is needed in the form of zakat or alms. Alms cleanse toxins in the soul and tend to reconstruct soul fragments efficiently. The hope, the soul, becomes sacred. When the soul is clean or pure, the character of individuals, groups, and corporations will appear better. Individuals and corporations must involve themselves in this religious activity because alms worship contains socioeconomic values.

Not only socioeconomic values but behind worship, there is prosperity and happiness. (McKinnon, 2014) stated that we must have given behavior for wealth and joy to be with us. Giving creates a symbiotic relationship - both parties benefit. The recipient benefits from providing the company, and the company gets real benefits because it has become a giver. The more individuals and corporations give more enthusiasm, energy, more age, and radiating excitement from individuals and corporations. Culture of giving is a form of awareness to get the potential to sell while improving the world through its actions, such as the culture of giving alms. Once the Almighty act of worship for individuals and corporations to be aware. The big question is, "does awareness of charity have the power to give and extend the company's life? It is because the power of giving birth to new spirits, happiness, and being on the hill of victory (Sumail and Pura, 2019) strengthens the hormone serotonin to extend the corporation's life. It makes sense to reason that alms awareness is characterized by religiosity, attitudes, subjective norms (Farouk et al., 2018) and moral reasons (Muhammad and Saad, 2016) so that they become a force of giving and will extend the life of the corporation.

The study designed is to obtain information about the power of providing alms and the impact on corporate age. The culture of giving will be influential and thrive when followed by organizational moral or ethical values (Mostovicz et al., 2012; Reverte, 2009; Reynolds and Yuthas, 2008). An optimistic tone conveyed by (Muhammad and Saad, 2016) that moral reasons can shape alms awareness. It is not enough just ethical reasons, but empirical evidence has identified related to the determinant variables of alms awareness. As (Farouk et al., 2018) stated, subjective attitudes and norms are related to charity's power. We believe that moral reasons underlie the awareness of paying zakat or giving alms so that individuals or corporations receive the hormone serotonin and extend the corporation's life.

In complete information, the research model is constructed based on reality. This study's unit of analysis is the owners, managers, and employees of the second generation of companies in Makassar. It believes, the second generation stage corporation is a corporation that has an awareness of alms and has a quality serotonin hormone.

The study's contribution to literature in four ways. First, explaining the phenomenon of alms awareness with the research analysis unit are the owners, managers, and employees of the second generation stage company in Makassar City. It believes, the second generation stage corporation is a corporation that has an awareness of alms and has a quality serotonin hormone. Second, it shows that research can be used or applied in real practice (charity behavior) or improve existing practices better. The third shows the 
influence of religiosity, attitudes, and subjective norms on awareness of charity and impact on the age of second-generation corporations. And the fourth was testing the serotonin hormone's role as a mediating variable and being a differentiator with previous research between charity awareness and corporate age.

The series of articles consists of: in section 2 of the literature review and hypothesis; in part 3 data and methodology; in section 4 results and discussion; in section 5 of the conclusion.

\section{THEORETICAL REVIEW}

The most significant contribution (Fishbein and Ajzen, 1975) about reasoned action or theory of reasoned action (TRA) can be used as a knife analysis to dissect intention behavior and awareness. The underlying assumption of TRA theory is that individuals reflect the consequences of their behavior before acting. Attitudes and subjective norms are constructs of TRA that can determine behavior. Attitude interpret as an overall evaluation of individuals towards the action of likes or dislikes of an object. At the same time, subjective norms are estimates of individual social pressure to conduct behavior (Ajzen, 2015). However, psychological theorists recognize that the two constructs are slightly relative and vary from one individual to another (Trafimow, 2009). Although TRA has significant limitations, many researchers still believe that TRA can reveal behavior levels in some scenarios (Trafimow, 2009). For example, behavior, personality uniqueness (extraction or introspection, official, etc.), social status, demographics, religiosity, and the like (Ajzen, 2012). (Saad and Haniffa, 2014a) argued about the suitability of using TRA to study zakat compliance or charity because zakat or charity is similar to current taxation.

Religiosity is a portrait of the appearance of behavior that has values, attitudes, and characters (Barro and McCleary, 2003; Lehrer, 2004). Therefore, religiosity reinforces awareness behaviors such as awareness of paying zakat or giving alms and can inhibit immoral or illegal conduct see (Torgler, 2006). Several studies have reported that religiosity has influenced certain behaviors to reduce fraud (Bloodgood et al., 2008). In ethical behavior (Keller et al.,, 2007), a robust mental health construct needs (Oakes, 2000), so that it can have a life purpose that is satisfaction and has inner welfare (Kate et al., 2017; Tiliouine and Belgoumidi, 2009). Therefore, in showing compliance behavior (Mohdali and Pope, 2014a), it will be filing and inhibiting criminals (Ellis and Peterson, 1996). Thus, religiosity recognizes as an essential factor in understanding human behavior, especially in shaping compliance behavior, henceforth becoming an awareness such as behavior alms awareness.

A concrete example of the role of religiosity has shown in research. For example, (Abdullah and Sapiei, 2018); (Bin-Nashwan et al., 2019); (Farouk et al., 2018); (Idris et al., 2012); (Mohdali and Pope, 2014b) states that the better the religiosity, the better the adherence of zakat or alms and the higher the awareness of paying zakat or giving alms. Then the hypothesis is stated:

H1: Religiosity is related to alms awareness.

Attitude is interpreted as the level of the like or dislike for specific actions. Attitude is born because there is a stimulus for beliefs, feelings, which are responded to by 
individuals based on the principle of cost-benefit (Ajzen, 2012; 2015). Hence, if the individual trusts and believes that the performance of the behavior will produce a positive impact, then the individual will have a favorable assessment and, at the same time, perform the reaction (Saad and Haniffa, 2014b).

Some researchers, including (Alim, 2015), (Abdullah et al., 2015), explained that the contribution of zakat or charity is quite effective in reducing poverty and inequality gaps so that the quality of life of the community is good. Therefore, like paying zakat or giving alms is a positive attitude, it becomes an awareness behavior. The most significant contribution of (Torgler, 2006) states that awareness of paying zakat or giving alms can inhibit immoral or illegal behavior. More and more research is proving that attitudes affect the behavior of paying zakat compliance and will be the behavior of paying zakat awareness or giving alms, such as research conducted by (Farouk et al., 2018); (Gopi and Ramayah, 2007); (Muhammad and Saad, 2016); (Ramayah et al., 2009). That is, the better the attitude, the higher the awareness of paying zakat or giving alms. Therefore, the second hypothesis of this study:

H2: Attitudes associated with alms awareness.

The context that an important part of TRA is subjective norms (Trafimow, 2009). (Yzer, 2017) supports (Ajzen's, 2012) view that subjective norms as individual evaluations of other individuals that are important to him will influence decisions related to the behavior. Often, individual subjective norms are born because of the demands of the social and environmental needs so that individuals try to meet the social environment's expectations. If the perception of social influence is positive, then the person will conduct awareness behavior paying zakat and giving alms. Subjective norms have a significant influence on intentions and behavior. For example, (Gopi and Ramayah, 2007); (Ramayah et al., 2009); (Saad and Haniffa, 2014b); (Taylor and Todd, 1995); (Yusuf and Derus, 2013). It believes, social perceptions influence awareness intentions and behavior in making zakat payments or giving alms (Ajzen, 2012; Andam \& Osman, 2016). Thus, the next hypothesis is as follows:

H3: Subjective norms relate to alms awareness.

Indeed, the culture of giving based on the awareness of paying zakat and giving alms is a noble work. (Sumail and Pura, 2019) stated that the consciousness or culture of giving is good behavior and sacred mission. Therefore, awareness of paying zakat or giving alms as God's mandate to build and maintain human welfare will extend individuals and corporations (Rahman, 2008; Tiliouine and Belgoumidi, 2009). Studies conducted by (Javaid and Al-Malkawi, 2018) that CSR (Zakat or charity) and corporate finance such as profitability and company value and can enhance company reputation (Kansal et al., 2014). A company that has a good reputation is a company that does not forget to share happiness with others.

Moreover, the recipient of happiness continues to pray for the company so that the company's life span is receiving longer. Because the higher the awareness of paying zakat or giving alms, the longer the company's life span and the more innovative (Parsons, 2015; Yusuf and Derus, 2013). Therefore, this study argues that: 
H4: Alms awareness is related to the age of the company.

There are indications that awareness of paying zakat or giving alms can increase the hormone serotonin. As a result, the hormone serotonin is essential for the human body because it helps manage a happy and positive mood, including preventing depression. A study revealed that serotonin levels' imbalance affects mood disorders that lead to stress, even depression (Ayala et al., 2012; Benton et al., 2008). Recognized or not, the higher awareness of paying zakat or giving alms increases the hormone serotonin and age increases. Therefore, the hormone serotonin can increase self-confidence for individuals and corporations. The higher the trust, the more passionate individuals or corporations pay zakat and giving alms (Mustafa et al., 2010; Nahar, 2018) so that age increases.

Accordingly, awareness of paying zakat or giving alms can display good and quality performance, such as social, economic justice (Wahab and Rahim, 2011). (Hati and Idris, 2014) published the result of a study that seemed to oppose the findings of (Wahab and Rahim, 2011). (Hati and Idris, 2014) begin with the assumption that customers' socioeconomic status and religiosity do not have a significant influence on their intention to channel their donations through Islamic social enterprises.

Conscious behavior paying zakat or giving alms is right and good. Even financial performance is having healthier and stronger stakeholder confidence by the company (Andrikopoulos et al., 2014; Angelia and Suryaningsih, 2015) so that the corporation's age increases. Hence, the next hypothesis is as follows:

H5: Alms awareness is associated with the hormone serotonin.

H6: Hormone serotonin is related to the age of the company.

H7: Alms awareness is related to the age of the company mediated by the hormone serotonin.

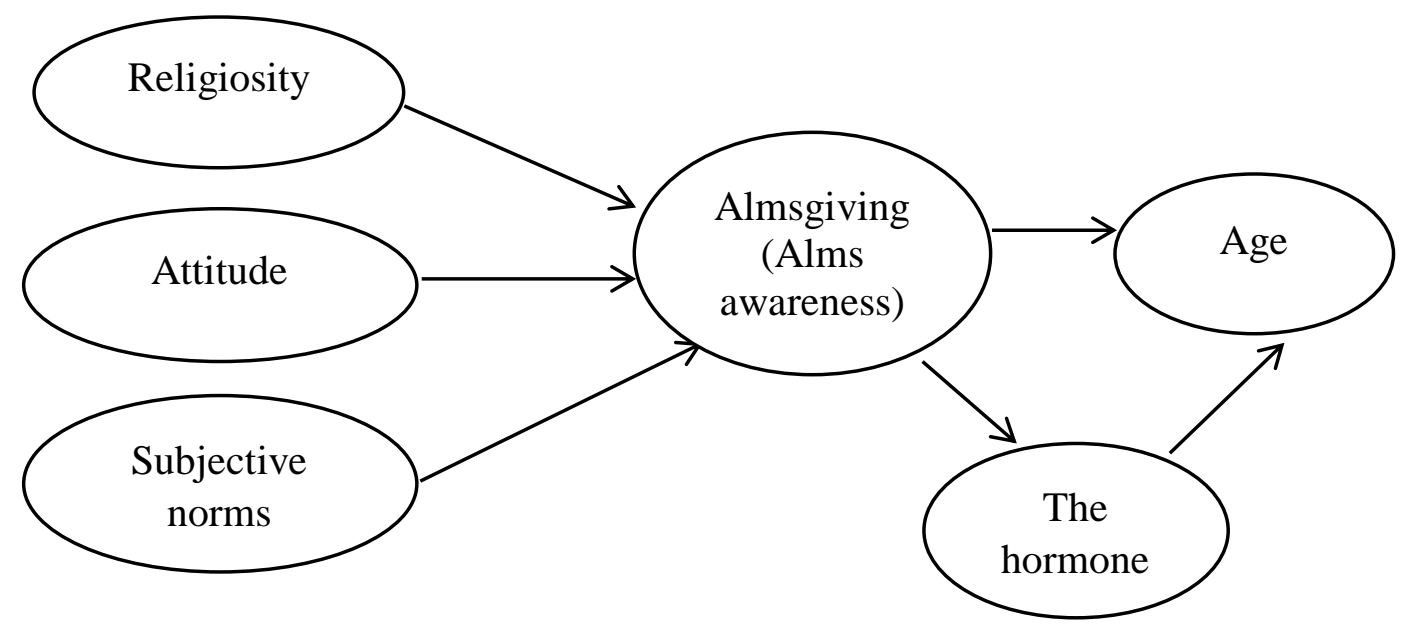

Figure 1. Research model 


\section{METHODS}

The research position in the company is in the second generation in Makassar City, namely PT Haji La Tunrung. The study attached to the individual and the unit of analysis is the owner or family, manager, and employee. The sample of this study is the owner, managers and some employees considering that they can provide excellent and correct information related to the issue of this study so that purposive sampling is an option in the sampling technique of 40 respondents.

To receive accurate and quality information from respondents, we designed the questionnaire using a Likert scale. We carried out the transformation of data from scores to data scales through the SolAnd 1.9 software application. Although this research sample is limited in number, we believe that analyzing data through the WarpPLS 7.0 software application can produce accurate and quality information (Solimun et al., 2017).

\section{RESULTS}

Social-Demographic Variables. Socio-demographic variables include age, gender, and formal education related to charity activities. Although there is a significant difference between 63 percent of female employees and 37 percent male, they are declared to have alms awareness. (Abdullah and Sapiei, 2018) reported that women tend to exhibit more dominant behavioral awareness than men. Alms awareness suspect by age. It found that the age of employees who work at PT Haji La Tunrung is 20-35 years old (56 percent) and age over 36 years (44 percent). They are employees who have alms awareness. However, alms awareness does not determine by age. (Hati and Idris, 2014) stated that age is not a determining factor in donating. Formal education owned by employees is a high school (64.7 percent) and undergraduate 35.3 percent. A higher level of formal education does not determine alms awareness. It is in line with revealed by (Abdullah and Sapiei, 2018) that format education has no relationship with alms awareness.

Goodness Model and Quality Index (Model Fit and Quality Indices). The average path coefficient (APC) is 0.455 (see Table 1). The average path coefficient is close to $50 \%$, so it can state that the explanatory variable (independent) can respond to the dependent variable. The average determinant correlation or Average R-squared (ARS) $=0.620$ is above $50 \%$ so that between variables is declared to have a relationship. Moreover, the association of several independent variables above $50 \%$ proved by the value of Average adjusted R-squared (AARS) $=0.608$. The three indicators of the goodness of this model have a p-value of $\mathrm{P}<0.001$. The data declared good, and the model can be said to be good because it is above 50\%. If APC, ARS, and AARS are close to or above 50\%, it stated that the model is feasible to provide an explanation and test of hypotheses (Sumail and Abdullah, 2019). 
Table 1. Model goodness and Quality Index

\begin{tabular}{lccc}
\hline \multicolumn{1}{c}{ Indicator of model goodness } & Fit Criteria & Analysis result & explanation \\
\hline$A P C$ & $\mathrm{p}<0,05$ & $0.455,(\mathrm{p}=0.001)$ & Good \\
ARS & $\mathrm{p}<0,05$ & $0.620,(\mathrm{p}=0.001)$ & Good \\
AARS & $\mathrm{p}<0,05$ & $0.608,(\mathrm{p}=0.001)$ & Good \\
& & & \\
Note: level of significance $p$-value $\alpha 0,05$ & & & \\
\hline
\end{tabular}

Combined Loadings and Cross Loadings. Indicators are constructed based on reality, theory, and research results. Table 2 presents data about combined loadings and crossloadings information. The goal is to check again (cross-check) whether the indicator is declared valid or fulfilled reliability. It turns out; all indicators said valid because of factor load $>$ cross-loadings or $\mathrm{p}<0.001$, and reliability performed because of Composite reliability coefficients> Cronbach's alpha coefficient (Solimun et al., 2017). Besides that, combined loadings and cross-loadings can also use as a standard measurement of the most important indicators or the strongest in reflecting a variable.

The most reliable indicator in reflecting religiosity at PT Haji La Tunrung is an ethical indicator of 0.854 . The stronger a person's moral values, the stronger the value of religiosity in shaping alms awareness. Ethical is a pattern of behavior or good habits based on religious values and accepted by one's social environment and ethical indicators. A person can have the strength of good religiosity if he can show his mental health so well that he tends to give alms.

Alms reflects a prominent attitude that is always displayed by owners, managers, and employees at PT Haji La Tunrung. The alms indicator weights 0.887 . The attitude of giving can create positive differences in others, feel more meaningful, even, and happy. However, it still found that the attitude of not giving alms tends to be low, especially for new employees who tend to have relatively small awareness.

The habit of giving alms by the owner, manager, and employee is a real form of parental reference with the essential factor of 0.886 . It is more prominent when compared to the owner/leadership referral indicator, which is 0.833 . It means subjective norms will be ethical if owners, managers, and employees strengthen parental references. The behavior of giving alms by the employees will be better if it supported by the encouragement of owner/leader references. 
Table 2. Combined Loadings and Cross Loadings

\begin{tabular}{|c|c|c|}
\hline & $\begin{array}{l}\text { Combined } \\
\text { Loadings }\end{array}$ & P-value \\
\hline \multicolumn{3}{|l|}{ Religiosity (reliability coefficients $=0.797>\alpha=0.691$ ) } \\
\hline ethical & 0.854 & $<0.001$ \\
\hline mentally healthy & 0.814 & $<0.001$ \\
\hline \multicolumn{3}{|l|}{ Attitude (reliability coefficients $=0.857>\alpha=0.667$ ) } \\
\hline Like & 0.887 & $<0.001$ \\
\hline Dislike & 0.306 & $<0.001$ \\
\hline \multicolumn{3}{|c|}{ Subjective norms (reliability coefficients $=0.819>\alpha=0.658$ ) } \\
\hline Parent's reference & 0.886 & $<0.001$ \\
\hline Owner / leadership reference & 0.833 & $<0.001$ \\
\hline \multicolumn{3}{|c|}{ Alms Giving Awareness (reliability coefficients $=0.856>\alpha=0.741$ ) } \\
\hline new spirit & 0.674 & $<0.001$ \\
\hline happiness & 0.940 & $<0.001$ \\
\hline on the hill of victory & 0.815 & $<0.001$ \\
\hline \multicolumn{3}{|c|}{ The hormone serotonin $($ reliability coefficients $=0.723>a=0.650$ ) } \\
\hline Mood (happy) & 0.818 & $<0.001$ \\
\hline Stress & 0.508 & $<0.001$ \\
\hline Cheerful & 0.856 & $<0.001$ \\
\hline \multicolumn{3}{|c|}{ Age of the company (reliability coefficients $=0.777>\alpha=0.663$ ) } \\
\hline The owner of a second-generation family member & 0.637 & $<0.001$ \\
\hline Featuring second-generation management & 0.688 & $<0.001$ \\
\hline
\end{tabular}

The values of religiosity, attitudes and subjective norms are related to alms awareness. Alms-awareness behavior leads someone to get happiness. It proved that the most crucial benefit of happiness indicators in reflecting alms awareness is 0.940 . Furthermore, the individual will be on the hill of victory and always exude a new spirit in all his daily activities.

The alms awareness behavior increases the hormone serotonin. When someone has an alms awareness, the individual tends to display a cheerful face. We find that carefree indicators have the most crucial factor of 0.856 in reflecting the hormone serotonin. Furthermore, followed by mood indicators (happy) of 0.818 and can reduce stress by 0.508. In addition to increasing the hormone serotonin, alms awareness behavior can also extend a corporation's life. As proof that the management showed is the second generation management style of managing a corporation with the most critical factor value of 0.688. It is quite reasonable if it stated that the corporation included in the second generation category is a family member as the owner. 
Table 3. Path coefficient result

\begin{tabular}{|c|c|c|c|c|}
\hline An explanatory variable & Response variable & Direct influence & p-value & \multirow{2}{*}{$\begin{array}{l}\text { Information } \\
\text { highly }\end{array}$} \\
\hline Religiosity (X1) & $\begin{array}{l}\text { Almsgiving awareness } \\
\text { (Y1) }\end{array}$ & $0.470 * * *$ & 0.001 & \\
\hline Attitude (X2) & $\begin{array}{l}\text { Almsgiving awareness } \\
\text { (Y1) }\end{array}$ & $0.434 * * *$ & 0.001 & $\begin{array}{l}\text { highly } \\
\text { significant }\end{array}$ \\
\hline Subjective Norms (X3) & $\begin{array}{l}\text { Almsgiving awareness } \\
\text { (Y1) }\end{array}$ & $0.303 * * *$ & 0.001 & $\begin{array}{l}\text { highly } \\
\text { significant }\end{array}$ \\
\hline Almsgiving awareness (Y1) & $\begin{array}{l}\text { The age of the company } \\
\text { (Y3) }\end{array}$ & $0.613 * * *$ & 0.001 & $\begin{array}{l}\text { highly } \\
\text { significant }\end{array}$ \\
\hline Almsgiving awareness (Y1) & Hormone serotonin $(\mathrm{Y} 2)$ & $0.583 * * *$ & 0.001 & \\
\hline Hormone serotonin (Y2) & $\begin{array}{l}\text { The age of the company } \\
\text { (Y3) }\end{array}$ & $0.327 * * *$ & 0.001 & $\begin{array}{l}\text { highly } \\
\text { significant }\end{array}$ \\
\hline $\begin{array}{l}\text { An explanatory } \\
\text { variable }\end{array}$ & Response variable & $\begin{array}{l}\text { Indirect } \\
\text { influence }\end{array}$ & & $\begin{array}{c}\text { The nature } \\
\text { of mediation }\end{array}$ \\
\hline $\begin{array}{l}\text { Almsgiving } \\
\text { awareness (Y1) }\end{array}$ & $\begin{array}{l}\text { The age of the } \\
\text { company (Y3) }\end{array}$ & $0.190 * * *$ & 0.001 & $\begin{array}{l}\text { Partial } \\
\text { mediation }\end{array}$ \\
\hline
\end{tabular}

Note: $* * *=$ highly significant at $\alpha=0.01 * *=$ significant at $\alpha=0.05 ; *=$ weakly significant at $\alpha=0.10$.

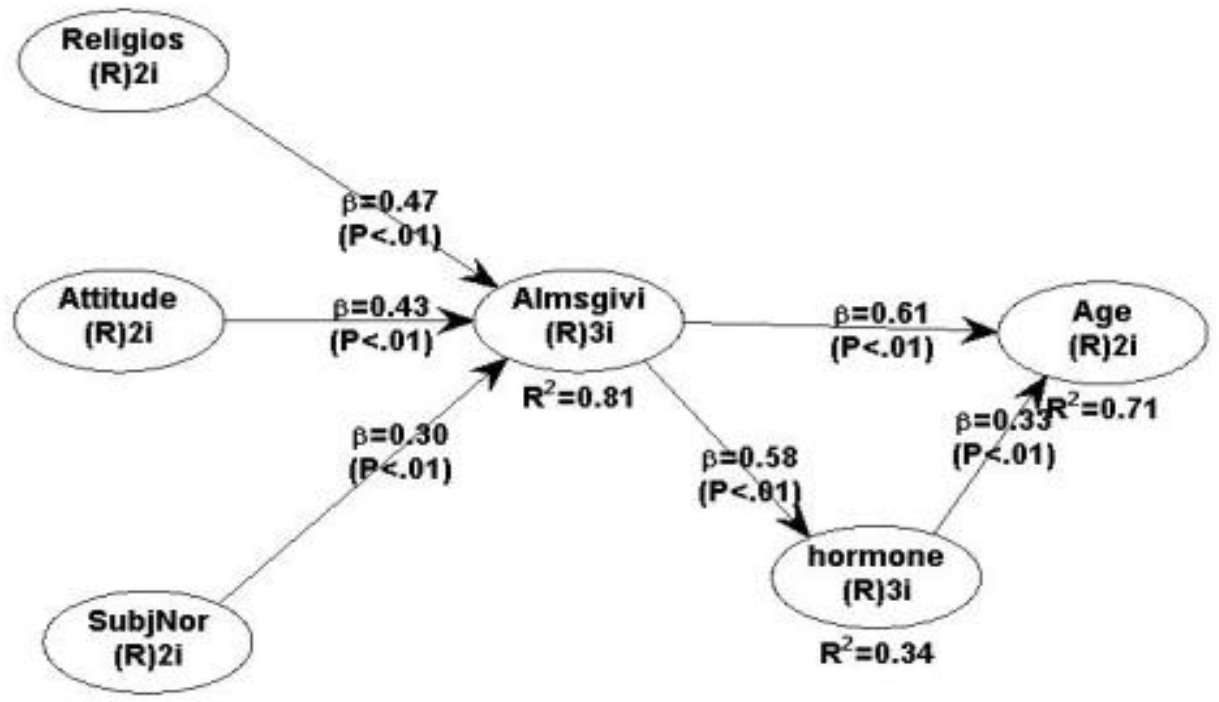

Figure 2. Model of research result

\section{DISCUSSION}

We found that religiosity can strengthen alms awareness for owners, managers, and employees at PT Haji La Tunrung. Because they believe that the meaning of the depth religiosity manifested in the act of giving alms. Long before, (Barro and McCleary, 2003); (Lehrer, 2004) stated religiosity is a portrait of the appearance of behavior, attitudes, and character and have values, such as charity culture. The most significant contribution of (Torgler, 2006) stated that religiosity reinforces awareness behaviors such as charity 
awareness and can inhibit immoral or illegal behavior. The power of religiosity influences specific actions such as reducing cheating (Bloodgood et al., 2008), inhibiting criminal behavior (Ellis and Peterson, 1996). It proved that the owners, managers, and employees always display ethical character suspected of the existence of religiosity. (Keller et al., 2007) stated that religiosity could encourage ethical character behavior, construct mental health to be sturdy (Oakes, 2000), achieve inner life satisfaction and welfare (Ten Kate et al., 2017); (Tiliouine and Belgoumidi, 2009) and display compliance behavior (Mohdali and Pope, 2014a). Therefore, religiosity recognized as an essential factor in understanding human behavior, especially in shaping obedience behavior, henceforth to alms awareness behavior.

It is reasonable to state that alms awareness behavior has socioeconomic values and leads to prosperity and happiness. Furthermore, the individual will be on the hill of victory and always exude a new spirit in all his daily activities. Articles (Sumail and Pura, 2019) reported that the power of giving could give birth to a new sense, happiness and being on the hill to victory can even extend the life of individuals or corporations. This study supported the previous research hypothesis. For example according to (Abdullah and Sapiei, 2018); (Bin-Nashwan et al., 2019); (Farouk et al., 2018); (Idris et al., 2012); (Mohdali and Pope, 2014b) that the better the religiosity, the better the obedience of alms and the higher the alms awareness of giving.

As it turns out, giving alms is a reflection of the prominent attitude that is always displayed by the owner, manager, and employees at PT Haji La Tunrung. The attitude of giving stimulus constructs by individuals benefits from giving birth to new relationships, a sense of power, a sense of happiness, peace, and love, and good health. Many researchers, including (Alim, 2015), (Abdullah et al., 2015), explained that alms contribution is quite effective in reducing poverty and inequality gaps so that the community's quality of life is good. Therefore, giving alms is a positive attitude so that it becomes an awareness behavior. Indeed, alms awareness is the expression of love for others. True love does not think of yourself. Through alms, he shows appearance invites to improve the perspective of life. We believe that almsgiving is the entrance to receive out of the zone of difficulty towards the zone of prosperity and happiness. This study supported the previous research hypothesis. As the study conducted by (Farouk et al., 2018), (Gopi and Ramayah, 2007), (Muhammad and Saad, 2016), (Ramayah et al., 2009) that the better the attitude, the higher the awareness of giving.

Owners, managers, and employees believe that charity awareness has socioeconomic values, prosperity, and happiness. Giving something meaningful to people's lives in need is a portrait of deposits in soul accounts that will increase sharply. Unexpectedly, all the conveniences and luck will come more profusely to individuals and corporations' lives because the universe glorifies the positive energy that has emitted. (McKinnon, 2014) stated that for prosperity and happiness to always be with us, giving and even creating a symbiotic relationship. The more individuals and corporations provide more enthusiasm, energy, age, and excitement that individuals and corporations get from the lives of individuals and corporations. The culture of giving is a form of awareness that receives the potential amount of happiness while improving the world through its actions, such as the culture of giving alms.

If the perception of socioeconomic influence is positive, then the individual and corporation will conduct alms awareness behavior. It is no exaggeration to mention that 
this study tends to support previous research hypotheses that subjective norms have a significant influence on intention and behavior. For example, (Gopi and Ramayah, 2007; Ramayah et al., 2009; Saad and Haniffa, 2014b; Taylor and Todd, 1995; Yusuf and Derus, 2013). It is believed, socioeconomic perceptions influence the intention and behavior of alms awareness (Ajzen, 2012; Andam and Osman, 2016).

Alms awareness behavior can extend the life of a corporation. Because, the awareness or culture of giving is good behavior and sacred mission in building and maintaining human welfare (Sumail and Pura, 2019). The habit of giving alms awareness is an embodiment of God's mandate to develop and sustain social protection and extend the corporation (Rahman, 2008; Tiliouine and Belgoumidi, 2009).

Currently, PT Haji La Tunrung is managing by second-generation management. They believe that alms awareness behavior can extend the life of individuals and corporations. As proof that the company's financial performance and reputation are excellent, it continues to fly. The habit of giving relegated to the second generation of management continues to proceed to the second generation. They realize that alms can cleanse poisons in the soul (detox) and reconstruct souls that have been and are being fragmented (split personality) so that it becomes a holy soul. When their souls are clean or pure, the character of individuals (owners, managers, and employees) and the corporation produces excellent performance, especially financial performance. Good business performance is a portrait that the company has managed well and with quality. A study conducted by (Javaid and Al-Malkawi, 2018) reported that CSR (Zakat or alms) has links to corporate finance, such as profitability and firm value. Almsgiving awareness can enhance a company's reputation (Kansal et al., 2014). A reputable company will extend the life of the company. Because of the higher almsgiving awareness, the longer the company's life span and the more innovative (Parsons, 2015; Yusuf and Derus, 2013).

The second-generation management by PT Haji La Tunrung always encourages employees to provide benefits to others. The alms awareness movement gives birth to new immunities and can increase the hormone serotonin. As a result, the hormone serotonin is particularly essential for the human body because it is beneficial in managing a happy and positive mood, including preventing depression. Alms can increase the hormone serotonin as proof that the owners, managers, and employees always display cheerful faces, attitudes (happy), and low levels of work stress and new enthusiasm. It is a sign that they already have the hormone serotonin so that the corporation's age increases.

A study revealed that the imbalance of serotonin levels affects mood disorders that lead to stress, even depression (Ayala et al., 2012; Benton et al., 2008). Recognized or not, the higher the awareness of giving alms increases the hormone serotonin and age increases. Therefore, the hormone serotonin can increase self-confidence for individuals and corporations. That is, the higher the trust, the more passionate individuals or alms corporate (Mustafa et al., 2010; Nahar, 2018) so that age increases. Alms-consciousness behavior symbolizes material success and spiritual abundance. When owners, managers, and employees always display alms behavior, they can achieve not only material wealth but also a spiritual success. The burning desire to have the power of giving is present in every human being. Therefore, the alms awareness movement brings victory to the buyer and the recipient. And therein lies the awesomeness of giving alms. For the management of PT Haji La Tunrung, alms awareness can improve financial performance and more substantial stakeholder confidence by the company. In this context, (Andrikopoulos et al., 
2014); (Angelia and Suryaningsih, 2015) have reported evidence that the more giving alms awareness of the financial performance and the more reliable stakeholders' trust the company, so that the age of the corporation increases.

\section{CONCLUSION}

Because the characteristics of PT Haji La Tunrung's ownership are family-owned and currently leads by second-generation family members, it is interesting to choose as the object of research related to alms awareness. Human beings do not fragment their souls (split personality) and easily infested with mental poisons, and we need a detox in the form of alms. Giving alms awareness will give birth to the hormone serotonin, and the corporate age will increase. We have the same view as (Abdullah and Sapiei's, 2018) that higher formal education levels are not the only determinant of alms awareness. We also found that women tend to be more dominant in showing awareness behavior compared to men. We find that the better religiosity, attitudes, and subjective norms, the higher giving the alms awareness, and the corporation's age increases. Sadaqah awareness can increase the hormone serotonin. Therefore, the hormone serotonin can increase self-confidence for individuals and corporations, and performance becomes useful so that the corporation's age increases.

Because we are in line with what was stated by (Abdullah and Sapiei, 2018) that format education has no relationship with charity awareness, future research focuses on non-formal education to measure culture on almsgiving awareness.

\section{REFERENCES}

Abdullah, M., and Sapiei, N. S. (2018). Do religiosity, gender, and educational background influence zakat compliance? The case of Malaysia. International Journal of Social Economics, 45(8), 1250-1264.

Abdullah, N., Derus, A. M., and Al-Malkawi, H. A. N. (2015). The effectiveness of zakat in alleviating poverty and inequalities a measurement using a newly developed technique. Humanomics, 31(3), 314-329.

Ajzen, I. (2012). The theory of planned behavior. Handbook of Theories of Social Psychology: Volume 1, 438-459.

Ajzen, I. (2015). The planned behavior theory is alive and well, and not ready to retire: a commentary on Sniehotta, Presseau, and Araújo-Soares. Health Psychology Review, 9(2), 131-137.

Alim, M. N. (2015). Utilization and Accounting of Zakat for Productive Purposes in Indonesia: A Review. Procedia - Social and Behavioral Sciences, 211(September), 232-236.

Andam, A. C., and Osman, A. Z. (2016). Factors influencing intention to give zakat on employment income: Experience from Marawi City. Journal of Islamic Accounting and Business Research, (August), 1-93.

Andrikopoulos, A., Samitas, A., and Bekiaris, M. (2014). Corporate social responsibility reporting in financial institutions: Evidence from Euronext. Research in International Business and Finance, 32, 27-35. 
Angelia, D., and Suryaningsih, R. (2015). The Effect of Environmental Performance And Corporate Social Responsibility Disclosure Towards Financial Performance ( Case Study to Manufacture, Infrastructure, And Service Companies That Listed At Indonesia Stock Exchange )

Ayala, I., Martos, N. F., Silvan, G., Gutierrez-Panizo, C., Clavel, J. G., and Illera, J. C. (2012). Cortisol, adrenocorticotropic hormone, serotonin, adrenaline, and noradrenaline serum, and concentrations concerning disease and stress in the horse. Research in Veterinary Science, 93(1), 103-107.

Barro, R. J., and McCleary, R. M. (2003). Religion and economic growth across countries. American Sociological Review, 68(5), 760-781.

Benton, J. L., Goergen, E. M., Rogan, S. C., and Beltz, B. S. (2008). Hormonal and synaptic influences of serotonin on adult neurogenesis. General and Comparative Endocrinology, 158(2), 183-190.

Bin-Nashwan, S. A., Abdul-Jabbar, H., and Aziz, S. A. (2019). Do enforcement, religiosity, and peer influence Zakah compliance behavior? International Journal of Financial Research, 10(6), 42-53.

Bloodgood, J. M., Turnley, W. H., and Mudrack, P. (2008). The influence of ethics instruction, religiosity, and intelligence on cheating behavior. Journal of Business Ethics, 82(3), 557-571.

Ellis, L., and Peterson, J. (1996). Crime and religion: An international comparison among thirteen industrial nations. Personality and Individual Differences, 20(6), 761-768.

Farouk, A. U., Md Idris, K., and Saad, R. A. J. Bin. (2018). The moderating role of religiosity on Zakat compliance behavior in Nigeria. International Journal of Islamic and Middle Eastern Finance and Management, 11(3), 357-373.

Fishbein, M., and Ajzen, I. (1975). Belief, Attitude, Intention, and Behavior: An Introduction to Theory and Research. Contemporary Sociology, 6 (2), 244-245.

Gopi, M., and Ramayah, T. (2007). Applicability of planned behavior theory in predicting intention to trade online: Some evidence from a developing country. International Journal of Emerging Markets, 2(4), 348-360.

Hati, S. R. H., and Idris, A. (2014). Antecedents of customers' intention to support Islamic social enterprises in Indonesia: socioeconomic, Socioeconomic status, religiosity, and organizational credibility. Asia Pacific Journal of Marketing and Logistics, 26(5), 707-737.

Idris, K. M., Bidin, Z., and Saad, R. A. J. (2012). Islamic religiosity measurement and its relationship with business income zakat and compliance behavior. Jurnal Pengurusan, 34, 3-10.

Javaid, S., and Al-Malkawi, H. A. N. (2018). Corporate social responsibility and financial performance in Saudi Arabia: Evidence from Zakat contribution. Managerial Finance, 44(6), 648-664.

Kansal, M., Joshi, M., and Singh, G. (2014). Advances in Accounting, incorporating Advances in International Accounting Determinants of corporate social responsibility disclosures: Evidence from India. International Journal of Cardiology.

Kate, J. Ten, Koster, W. De, and Waal, J. Van Der. (2017). The Effect of Religiosity on Life Satisfaction in a Secularized Context: Assessing the Relevance of Believing and Belonging. Review of Religious Research, 59(2), 135-155. 
Keller, a. C., Smith, K. T., and Smith, L. M. (2007). Do gender, educational level, religiosity, and work experience affect the ethical decision-making of U.S. accountants? Critical Perspectives on Accounting, 18(3), 299-314.

Lehrer, E. L. (2004). Religion as a determinant of economic and demographic behavior in the United States. Population and Development Review, 30(4), 707-726.

McKinnon, A. J. (2014). The Power of Giving (Keempat ed.). Jakarta: Phoenix Publishing Project.

Mohdali, R., and Pope, J. (2014a). The influence of religiosity on taxpayers' compliance attitudes Empirical evidence from a mixed-methods study in Malaysia. Accounting Research Journal Vol., 27(1), 71-91.

Mohdali, R., and Pope, J. (2014b). The influence of religiosity on taxpayers' compliance attitudes Empirical evidence from a mixed-methods study in Malaysia. Accounting Research Journal, 27(1), 71-91.

Mostovicz, I., Kakabadse, N., Kakabadse, A., Mostovicz, I., Kakabadse, N., and Kakabadse, A. (2012). CSR : the role of leadership in driving ethical outcomes.

Muhammad, S. A., and Saad, R. A.-J. (2016). Moderating Effect of Attitude toward Zakat Payment on the Relationship between Moral Reasoning and Intention to Pay Zakat. Procedia - Social and Behavioral Sciences, 219, 520-527.

Mustafa, M. O. A., Mohamad, M. H. S., and Adnan, M. A. (2010). Antecedents of zakat payers' trust in an emerging zakat sector: an exploratory study. Journal of Islamic Accounting and Business Research, 4(1), 4-25.

Nahar, H. S. (2018). Exploring stakeholders' views on a corporatized zakat institution's management performance. International Journal of Ethics and Systems, 34(4), 608631.

Oakes, K. E. (2000). Reflection on religiousness and mental health. Counseling and Values, 44(2), 113-117.

Parsons, R. A. (2015). The impact of age on innovation. Management Research Review, $38(4), 404-420$.

Rahman, S. (2008). Zakat on Reinterment and Pension Plans. International Journal of Islamic and Middle Eastern Finance and Management, 5(2), 134-156.

Ramayah, T., Rouibah, K., Gopi, M., and Rangel, G. J. (2009). A decomposed theory of reasoned action to explain intention to use Internet stock trading among Malaysian investors. Computers in Human Behavior, 25(6), 1222-1230.

Reverte, C. (2009). Determinants of Corporate Social Responsibility Disclosure Ratings by Spanish Listed Firms Carmelo Reverte, 351-366.

Reynolds, M., and Yuthas, K. (2008). Moral Discourse and Corporate Social Responsibility Reporting, 47-64.

Saad, R. A. J., and Haniffa, R. (2014a). Determinants of zakah (Islamic tax) compliance behavior. Journal of Islamic Accounting and Business Research, 5(2), 182-193.

Saad, R. A. J., \& Haniffa, R. (2014b). Determinants of zakah (Islamic tax) compliance behavior. Journal of Islamic Accounting and Business Research, 5(2), 158-181.

Sumail, L. O., and Abdullah, S. (2019). Innovative Behavior And Emotional Intelligence Of Managers In Managing A Catering Business. Jurnal Manajemen, 23(2), 290.

Sumail, L. O., and Pura, R. (2019). Corporate Social Responsibility Based on Essential Awareness. Jurnal Manajemen, 23(1), 1-18. 
Solimun., Adji A. R., dan Nurjannah. (2017). Metode Statistika Multivariat: pemodelan Persamaan Struktural (SEM) Pendekatan WarpPLS. UB Press Malang.

Taylor, S., and Todd, P. (1995). Decomposition and crossover effects in the theory of planned behavior: A study of consumer adoption intentions. International Journal of Research in Marketing, 12(2), 137-155.

Tiliouine, H., and Belgoumidi, A. (2009). An exploratory study of religiosity, meaning in life and subjective wellbeing in Muslim students from Algeria. Applied Research in Quality of Life, 4(1), 109-127.

Torgler, B. (2006). The importance of faith: Tax morale and religiosity. Journal of Economic Behavior and Organization, 61(1), 81-109.

Trafimow, D. (2009). The Theory of Reasoned Action: A Case Study of Falsification in Psychology. Theory \& Psychology, 19(4), 501-518.

Wahab, N. A., and Rahim Abdul Rahman, A. (2011). A framework to analyze the efficiency and governance of zakat institutions. Journal of Islamic Accounting and Business Research, 2(1), 43-62.

Yusuf, M. B. O., and Derus, A. M. (2013). The measurement model of corporate zakat collection in Malaysia: A test of diffusion of innovation theory. Humanomics, 29(1), 61-74.

Yzer, M. (2017). Theory of Reasoned Action and Theory of Planned Behavior. The International Encyclopedia of Media Effects, 1-7. 